\title{
Status of derivative works of scientific publications under copyright law and publication standards
}

\author{
Justyna Ożegalska-Trybalska
}

Intellectual Property Law Chair, Jagiellonian University, Kraków, Poland

Introduction. The article aims to present the principles of derivative works (including translations) of original and others' scientific publications in copyright law and publication standards.

Material and methods. The analysis concerns the legal status of derivative works as so-called derivative (dependent) works under copyright law, with the indication of the practice of regulating dependent rights relevant to derivative works in publishing contracts and publication guidelines.

Results and discussion. Works prepared on the basis of original work and translations of works have a special status in copyright law. On the one hand, they are subject to the personal and economic copyrights of the person who created them, while on the other, the exploitation of such derivative works is subject to the consent of the author of the original work based on the construction of the so-called dependent copyrights. In practice, this category of work may create uncertainty as regards the proper grounds for exploitation of such modified scientific publications by other authors, as well as problem of unreliable duplication of one's scientific achievements in the form of modified versions of previous work.

Summary. The condition for the authorised preparation and exploitation of derivate works by other authors requires an awareness of the regulations concerning this category of work, as well as consideration of previous contractual provisions concerning the disposal of dependent rights to the original works on which they were based.

NOWOTWORY J Oncol 2020; 70, 2: 118-120

Key words: derivative works, translations, modification of scientific publications, copyrights and translations, dependent copyrights.

\section{Introduction}

The characteristic of scientific research activities in the field of medicine, the interest in accessing translations of recent foreign medical publications, and the dissemination of one's works abroad are conducive to the preparation of modified or translated versions of scientific texts. This is due to the scientific and application attractiveness of updated research results (even if the initial results have already previously been described) and the universal applicability of medical discoveries, methods of treatment and diagnosis, which makes it possible to publish the same scientific papers in different language versions.

In terms of copyright law and publishing standards, the derivate works raise several important issues. Firstly, it should be clarified whether the elaboration (translation) of someone else's work has the nature of independent creative activity and results in the acquisition of copyright on such results, and whether it is necessary for the author (the entity authorised to do so) to the original work (translated or modified) to agree on such exploitation. Secondly, it is important to determine

\section{How to cite:}

Ożegalska-Trybalska J. Status of derivative works of scientific publications under copyright law and publication standards. NOWOTWORY J Oncol 2020; 70: 118-120. 
whether regulations concerning this kind of creativity are required in contracts with publishers. Thirdly, the problem of qualifying various versions of scientific works (translations) as competitive publishing positions, duplicating scientific achievements or even constituting so-called self-plagiarism, arises in relation to derivate works.

\section{Material and methods}

According to the standard provided by international regulations [1], copyright law protects not only original works but also so-called derivative works, including translations. A regulation in this respect is expressed in Article 2 Section 1 of the Act on Copyright and Related Rights of 14 February 1994 [2], which states that the development of someone else's work, in particular translation and modification, is subject to copyright, without prejudice to the right to the original work. Within the meaning of this provision, the derivate work is a recognisable appropriation of the content and often the form of the original work [3], which takes place by taking the creative elements of the original work and adding other creative elements by the person who prepares the derivate work. The creative contribution may be a result of the addition of new descriptions and comments, the selection of certain elements and their ordering, and so on. Creative elements are not the pure research data contained in the work, which as such are not protected by copyright. From the copyright point of view, there is a freedom to reprint them (e.g. as the results of final research, despite the previous publication of preliminary research) in subsequent scientific publications. Therefore, only updating the results of research contained in a work, as well as making editorial changes, corrections, shortening the text without any substantive changes, or changing the form of the original work, do not constitute a derivative work.

One type of derivative work is the translation of someone else's work, in relation to which it is assumed that a person making even a literal translation has a certain scope of freedom and creatively contributes to the translation. In practice, translations of foreign-language medical articles are often accompanied by additional comments, which adds additional creative input and may result in joint ownership of an article. A scientific publication that is inspired by someone else's work, including a work devoted to the same medical problem, describing similar research results, based on a similar methodology, and so on, is not a derivate work.

\section{Results and discussion}

The special legal status of derivate works (translations) in copyright law is a result of the difficult construction of so-called dependent copyrights linked with this type of intellectual creation. The exploitation and contractual regulation of such may lead in practice to certain misunderstandings, disputes about copyright infringement, or allegations of unreliable reproduction of the results of scientific activity.
On the one hand, preparing a derivative work of one's own or someone else's work means creating an independent copyright work, to which the authors of the study have moral and economic copyrights. From the legal point of view, the new version of an earlier scientific publication (including the language version) is, therefore, a subsequent, but separate, independent work. However, a different qualification in this respect may result from the standards for the evaluation of scientific achievements. According to these, derivative works as being devoid of new scientific character are those that duplicate the scientific achievements, and their demonstration may give rise to an allegation of scientific unreliability, and are sometimes wrongly qualified as self-plagiarism [4]. On the other hand, derivative works have the status of so-called dependent works due to their connection with the original work. This is expressed in the obligation to obtain the consent of the author of the original work to use and dispose of the derivative work (but not to make the study/translation itself), as well as to respect personal copyrights, including mention of the name of the author and the title of the original work in the copies of the modified work (art. 2 sec. 2 and 5 of the copyright law). Special rules of exploitation of studies (translations) as dependent works are a consequence of the author of the work being entitled not only to personal and economic rights, but also so-called dependent copyrights. These guarantee the author both the acquisition of rights to the original work, but also rights to "secondary" works created on its basis, including derivate works such as e.g. translations. The consent to use the dependent rights to a work should result from an explicit contractual provision or the explicit consent of the holder. In practice, it is a common mistake to assume that regulating the use of an author's economic rights to the original work (under transfer agreement or licence agreement) results in the freedom to modify, develop or translate it. In this respect, Article 46 of the Copyright Act should be borne in mind. It states that even if, on the basis of a contract, the transfer of all economic copyrights to a work takes place, unless the contract provides otherwise the author retains the exclusive right to permit the exercise of dependent copyright to the work.

\section{Summary}

To avoid potential problems with scientific works constituting derivative works, including translation of other works, the following proposals may be helpful to authors and those who publish, make available or disseminate modified or translated scientific work.

Firstly, for the authorised use of the derivate work based on one's own or someone else's original work, having the economic rights to the original work or a licence is not sufficient. Concerning someone else's work as developed or translated, it is necessary to have permission to exercise the rights dependent on the author of the original work or the entity that holds them (which also applies if the publisher commissions 
its translators to translate scientific texts). In the case of one's own works, the provisions of previous agreements on the disposal of dependent rights to the original work should be respected (it should be ensured that the dependent rights to the original work have not been transferred to another entity (e.g. the publisher) or consent to the exercise of subsidiaries has not already been given).

Secondly, the exploitation of rights to a derivative work requires the assurance of personal copyrights by placing the name and title of the work on the study next to the author(s) of the derivative work. Using and disposing of a derivative work without meeting the conditions does not affect the creation of copyrights to the such work, but may result in an allegation of infringement of the rights to the original work, including the prohibition of use and a claim for compensation [5].

Thirdly, in the case of regulating dependent rights in publishing agreements, a conflict of interest for the author of a scientific work may arise in relation to keeping dependent rights to the work and the publishing house, which may be interested in securing its rights and acquiring dependent rights to eliminate a potentially competitive publication in the form of a study (translation) of such work elsewhere.

Fourthly, the qualification of derivate scientific works as independent works within the meaning of copyright is an issue that should be distinguished the existing restrictions on the publication and indication of such works as a part of scientific achievement. They are a result of the publishing rules applied by publishers, as well as codes of ethics relating to standards of scientific creation, based on the criterion of "originality of the work", scientific value, or competitiveness of the published content [6]. In this respect, ethical standards of publishing may apply, according to which the re-publishing of the same scientific work (or its essential parts) should be accepted by the publisher and should include a reference to the first publication of the work. Moreover, according to these standards, derivative works and their essential parts should be treated as a single publication in the author's scientific achievements [7].

Conflict of interest: none declared

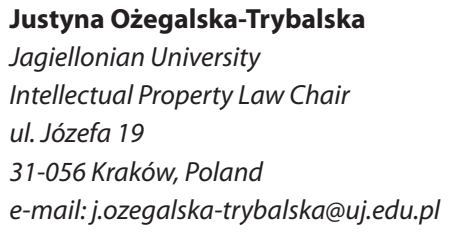

Received and accepted: 21 May 2020

\section{References}

1. Dz. U. z 2019 r. poz. 1231.

2. Berne Convention for the Protection of Literary and Artistic Works of 9 September 1886, revised in Berlin on 13 November 1908 and in Rome on 2 June 1928. (ratified in accordance with the Law of 5 March 1934), OJ L 287, 31.10.1934. 1935 No 84 item 515.

3. Traple E. In: Barta J, Markiewicz R. ed. Prawo autorskie i prawa pokrewne. Komentarz. Wolters Kluwer, Warszawa 2010: 49.

4. Stanisławska-Kloc S. Plagiat contra autoplagiat. In: Spory o własność intelektualną. Księga jubileuszowa dedykowana Profesorom Januszowi Barcie i Ryszardowi Markiewiczowi. Wolters Kluwer, Warszawa 2013: 1111-1114.

5. Decision of the Polish Supreme Court of 28.11.2006 r., IVCSK 203/06, LEX nr 39175.

6. See e.g Publishing ethical standards, Medycyna Praktyczna. https:// www.mp.pl/onas/etyka_wydawnicza/205515,zasady-etyki-wydawniczej (02.05.2020).

7. Code of Ethics for Research Workers. Second Edition (adopted by the Science Ethics Committee and enacted by the General Assembly of the Polish Academy of Sciences on 1 December 2016. https://instytucja. pan.pl/index.php/kodeks-etyki-pracownika-naukowego (02.05.2020). 